\title{
Application of Pyrolysis Acid from Date Palm Waste as Wood Preservative
}

\author{
Ghanbar Ebrahimi, ${ }^{\mathrm{a}, *}$ Peyman Ahmadi, ${ }^{\mathrm{a}}$ Davood Efhamisisi, ${ }^{\mathrm{a}}$ and Alireza Shakeri ${ }^{\mathrm{b}}$ \\ Matched sets of clear specimens of poplar and pine wood were treated \\ with 3,5 , and $8 \%(\mathrm{v} / \mathrm{v})$ aqueous solutions of slow pyrolysis acid (PA) \\ derived from date palm waste, to evaluate the effectiveness of PA in \\ controlling mold growth on species of wood. Chemical compounds \\ available in PA were identified by gas chromatography-mass spectrometry \\ analysis. Treated and control specimens were contaminated with \\ Aspergillus sp., then incubated in accordance to AWPA E24 (2017). \\ Percentages of occupied surface by mold on each of control and treated \\ specimen with respect to its total surface were evaluated by Image-J \\ software. Comparisons of mean values of these determined ratios and \\ physical examinations showed that, depending on species, the 5 and $8 \%$ \\ water solutions of PA prohibited Aspergillus growth on tested woods. \\ Experiments were also conducted on a matched set of small clear \\ specimens of beech wood, impregnated by 3,5 , and $8 \%$ water solutions \\ $(\mathrm{v} / \mathrm{v})$ of $\mathrm{PA}$, using full-cell process and contaminated with decay fungus \\ (Trametes versicolor), then incubated. Specifications of the EN 113 (1996) \\ standard were followed. Weight loss was applied for comparing control \\ and treated specimens. Average values of weight losses indicated that the \\ $5 \%$ solution was effective, but $8 \%$ solution presented a better result.
}

Keywords: Palm groove; Waste; Pyrolysis acid; Organic preserver

Contact information: a: Department of Wood and Paper Science \& Technology, Faculty of Natural Research, University of Tehran, Karaj, Iran; b: School of Chemistry, College of Science, University of Tehran, Tehran,Iran; *Corresponding author: ba_ebrahimi@yahoo.com

\section{INTRODUCTION}

With 250,000 ha of date palm grooves, Iran is one of the major date producers in the world. High quality date is harvested from approximately $40 \%$ of these groves. About 15 dried rachis are trimmed or pruned from each palm tree every year. The statistical figure of the weight of trimmed rachis (fronds) is around 2,200,000 tons (Ahmadi et al. 2015). Enormous waste is produced during this time, and the weights of slashed tree trunk or stem scattered through groves must be added. Thus, these two items will result in a large amount of lignocellulosic wastes.

Thus far these wastes are not properly utilized, while they could be used for producing organic pesticide and biochar through slow pyrolysis. Date farmers disperse them and burn them in the groves, but they are not evenly distributed, which results in piles of ash on the soil.

Date palm (Phoenix dactylifera) residues are fibrous materials. In recent years, the properties and elemental composition of these wastes were studied on a laboratory scale (i.e., Tables 3, 4, and 13 in Jonoobi et al. 2019). These studies were made with the purpose of replacing wood in its fiber-based composites, such as various panels, structural composite lumber, or paper products, because their fibrous nature and fabricated 
experimental specimens have shown promise (Jonoobi et al. 2019). It must be noted that workability of date palm residues is not like other wood species, including the shearing parallel-to-grain and cleavage, which are comparatively high in these wastes, particularly in rachis. Conventional adhesive (urea formaldehyde) that is used for producing woodbased panels does not cure on these wastes' bark-containing particles as well as it does on wood particles, because their barks are siliceous. Thus, the material ought to be debarked or defibrated, which is an energy-consuming process.

An alternative solution would be replacing the adhesive with an expensive type. The fronds (rachis) are tough substances when compared with woods. They are considered to be high tool wearing materials. In view of replacing wood with these wastes in woodbased productions, field-scale studies on alloy of crushing blades need to be conducted. Additionally, comprehensive industrial studies are required related to the manufacture of fiber-based products out of these wastes with common adhesive, in terms of exploring environmental pollution and mechanism of the impact of such products on human's living environment. Performances of these types of composites are not well known yet, and bringing formaldehyde through inclusion of an adhesive to the living environment of humans is not recommended. Many industrial installations with the purposes of profitability and job openings have been established, but later on they were recognized as causes of environmental problems and global climate change.

An important point related to producing fiber-based products out of date palm wastes is the continuous removal of these residuals from date palm groves. This action in the long run will degrade groves' soils with respect to their fertility and nutrient balance. Such results in other cultivation areas about crops residuals have been substantiated (Prasad and Power 1991).

Fortunately, during the last two decades the concept of conversion of crop biomass through thermochemical process (pyrolysis) into a substance that could be returned to soils under cultivations, has been developed. This form of biomass application has been extended to date palm wastes as well. Many useful research studies on topics such as: properties of biochar (Ronsse et al. 2013; Gai et al. 2014; Jouiad et al. 2015; Bensidhom et al. 2018), cases of its use as green sorbents of organic and inorganic pollutants (Usman et al. 2015, 2016; Al-Wabel et al. 2019), improving soil fertility, upgrading and remediating degraded soils (Beesley et al. 2011; Hussain et al. 2014; Al-Wabel et al. 2019), climate change mitigation (Woolf et al. 2010; Skjemstad et al. 2002), etc., have been published. In all of these studies the functions of biochar were evaluated positively with no doubt. Conducting pyrolysis process is not harmful for the environment and would not cause any net greenhouse gas emissions. Pyrolignous gases in pyrolyzing biomass are condensable by a proper designed system (Hussain et al. 2014).

The other pyrolytic product is liquid that results from condensing volatiles that emit from pyrolyzing reactor. This liquid in recent studies is called pyrolysis acid (PA) (Hussain 2015), while it contains several organic applicable chemicals. Thus, to identify these compounds, a deliberate characterization of this PA is needed.

This study was conducted to characterize PA from date palm waste as a wood preservative. The main objectives in this investigation were to evaluate the preserving potential of PA on two species of wood (poplar and pine) against mold growth and beech wood against rotting fungus. 


\section{EXPERIMENTAL}

\section{Materials}

In this research, date palm waste samples were collected from palm grooves in Lamerd (southern territory of Fars province of Iran). Test materials were air-dried to $10 \%$ average moisture content, then chipped into particles that measured 10 to $15 \mathrm{~mm}$ in length and up to $5 \mathrm{~mm}$ in thickness. Then, the prepared waste particles were pyrolysed in a laboratory-scale pilot electrical furnace that was designed by others with a temperature level up to $350{ }^{\circ} \mathrm{C}$ (Fig. 1). The furnace was equipped with programmable control panel for time-based temperature. Temperature increment was set as $5^{\circ} \mathrm{C} \cdot \mathrm{min}^{-1}$. The weight of test load for pyrolysis ranged from 500 to $1000 \mathrm{~g}$. Total residential time was $5 \mathrm{~h}$. Emitted volatiles from furnace were transferred through steel pipe to a condensing system, which comprised small diameter sloped spiral stainless steel and being bedded in mixture of ice cubes and water at temperature around $0{ }^{\circ} \mathrm{C}$. Condensed PA was collected in a transparent bottle with liquid and gas tight lid. At the end of predetermined residential time (experimentally determined by stopping oil droplet falling into bottle), power was switched off and as a precautionary measure the apparatus was allowed overnight to cool off. Then, the furnace was unloaded, and weights of biochar and PA were determined.

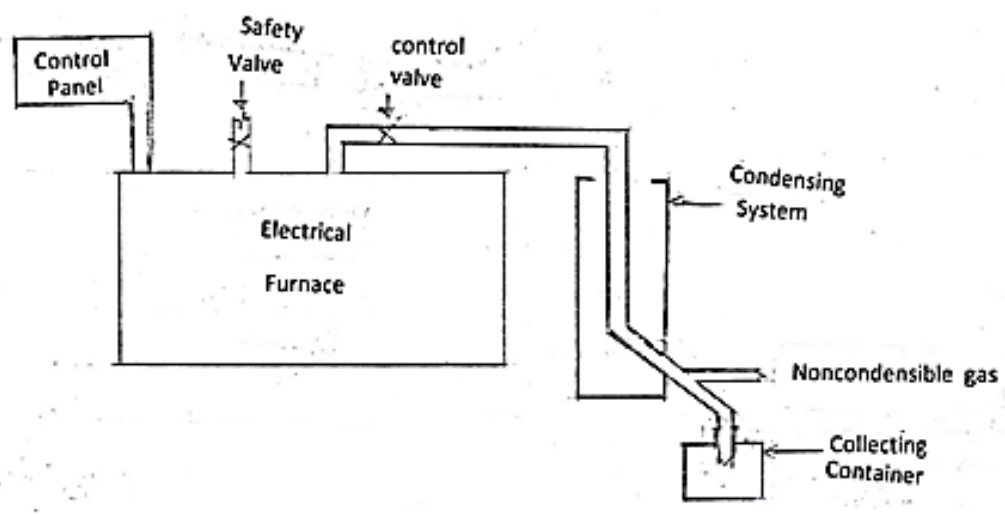

Fig. 1. Schematic diagram of pyrolysis apparatus

\section{Methods}

PA analysis

The liquid-liquid extraction was carried out by adding ethyl acetate (Merck, Darmstadt, Germany). Next, $1 \mathrm{~mL}$ of the organic fraction was transferred to a gas chromatography vial and was analyzed by gas chromatography-mass spectrometry (GC/MS) using an Agilent 7890A gas chromatograph (Agilent Technologies, Santa Clara, CA, USA) coupled to an Agilent 5975C VL MSD mass spectrometer. The GC separation was performed on a Rtx 5 MS capillary column with a length of $30 \mathrm{~m}$, internal diameter of $0.25 \mu \mathrm{m}$, and a film thickness of $0.25 \mathrm{~m}$.

As mentioned earlier in the objectives of this study, it was proposed to investigate the ability of PA in preventing mold growth on solid wood items and also controlling a damaging fungus in a susceptible wood species.

\section{Characterization of PA as wood preservative}

Two species of wood, namely poplar $(P$. deltoides $)$ and pine $(P$. eldarica) were treated with the PA derived from pyrolysis date palm waste and contaminated by mold 
(Aspergillus niger), after being incubated for a two-week period the evaluation of mold's growth was determined by application of the software image-J (National Institutes of Health, Bethesda, MD, USA).

For testing the effectiveness of PA in protecting wood against damaging fungus, beech wood (Fagus orientalis) was nominated, because wood of this species is mostly damaged by Trametes versicolor.

\section{Mold growth test}

Four sets of matched specimens were prepared from each species. Dimensions of each specimen were $4 \times 1 \times 2 \mathrm{~cm}^{3}$ (length $\times$ thickness $\times$ width). Specimens had $10 \%$ moisture content. One set of specimens of each species was considered as control agent, the second set of specimens was impregnated by $3 \%$ (by weight) water solution of PA, the third set by $5 \%$, and the last set by $8 \%$ solution through a full-cell process. Through testing, it was observed that PA was completely water miscible.

All four sets of specimens of individual species were contaminated by Aspergillus (mold) and incubated under standard conditions for two weeks (AWPA E 24 2017). After the mentioned incubation period, the percentage of surface in individual specimens occupied by the mold with respect to its total surface was evaluated using image-J software.

\section{Control of decay fungus}

Following the same procedure as in the mold test, four sets of specimens from beech wood $(F$. orientalis) were prepared for testing. Every set of specimens consisted of 6 specimens, each with dimensions of $50 \times 2.5 \times 1.5 \mathrm{~mm}^{3}$ (longitudinal $\times$ radial $\times$ tangential) and $10 \%$ moisture content. The first set was not treated as control, but the second, third, and fourth sets were impregnated with 3,5 , and $8 \%$ (by weight) water solution of bio-oil, respectively, by applying conventional full-cell process. The initial vacuum for $10 \mathrm{~min}$ (0.7 bar) was applied to remove air from wood cavities. Then, the impregnation solution was introduced to the laboratory-scale vessel. Thereafter, the pressure was increased up to 5 bar and held for $2 \mathrm{~h}$. Finally, 5 min vacuum was applied at the end of the process. The control set was soaked in water to saturate. Grown pieces of fungus (Trametes versicolor) were placed on the specimens, and then they were incubated for 16 weeks under desired condition of temperature and humidity for fungus growth, carried out in accordance with EN 113 (1996) standard. All specimens were weighed at the end of conditioning period. The weight losses of specimens with respect to their weight after impregnation were calculated.

\section{RESULTS AND DISCUSSION}

Results of this process revealed major changes in compositions, as shown in Table 1. Table 1 shows that PA contained six predominant compounds, namely acetone, acetic acid, furfural, phenol, and 1,2-benzenedicarboxylic acid, 3-nitro. Among these compounds, acetic acid has a higher percentage of availability in GC-MS analysis. These six compounds were bioactive in controlling growth of mold and decay of fungus on tested wood species. The pyrolysis derived PA out of oil palm stem functions as an antifungal and antitermitic agent at same time (Oramahi et al. 2018). 
Table 1. Identified Compositions in PA

\begin{tabular}{|c|c|c|c|c|}
\hline No. & $\begin{array}{c}\text { Retention Time } \\
(\mathrm{min})\end{array}$ & Compound Name & Area (\%) & $\begin{array}{c}\text { Mol. Weight } \\
(\mathrm{g} / \mathrm{mol})\end{array}$ \\
\hline 1 & 1.601 & Acetone & 2.03 & 58.042 \\
\hline 2 & 1.71 & Methyl acetate & 15.55 & 74.037 \\
\hline 3 & 2.428 & Acetic acid & 52.30 & 60.021 \\
\hline 4 & 5.781 & Furfural & 17.58 & 96.021 \\
\hline 5 & 8.994 & Phenol & 5.89 & 94.042 \\
\hline 6 & 26.451 & $\begin{array}{c}1,2-\text { Benzenedicarboxylic acid, 3- } \\
\text { nitro- }\end{array}$ & 6.65 & 211.012 \\
\hline
\end{tabular}

Average retentions of PA in poplar specimens treated by 3, 5, and $8 \%$ were calculated as $0.286,0.336$, and $0.965 \mathrm{~g}$, respectively. In pine specimens, in the same order the PA retentions were determined as $0.123,0.296$, and $0.402 \mathrm{~g}$.

Table 2. Data of Mold Growth Experimentation on Poplar and Pine Wood Specimens Treated with PA with Tentative Statistical Measure

\begin{tabular}{|c|c|c|c|c|c|c|c|c|c|}
\hline \multirow[t]{2}{*}{ Source } & \multirow{2}{*}{$\begin{array}{l}\text { Sample } \\
\text { Set }\end{array}$} & \multirow[t]{2}{*}{ No. } & \multirow{2}{*}{$\begin{array}{l}\text { Initial } \\
\text { Weight } \\
\text { (g) }\end{array}$} & \multirow{2}{*}{$\begin{array}{c}\text { Weight } \\
\text { After } \\
\text { Treat- } \\
\text { ment }(\mathrm{g})\end{array}$} & \multirow{2}{*}{$\begin{array}{l}\text { Retention } \\
\text { (\% of } \\
\text { Initial } \\
\text { Weight) }\end{array}$} & \multicolumn{2}{|c|}{$\begin{array}{l}\% \text { Weight of Oil } \\
\text { in Specimen }\end{array}$} & \multicolumn{2}{|c|}{$\begin{array}{c}\% \text { of Occupied } \\
\text { Surfaces to Total } \\
\text { Specimen Surface }\end{array}$} \\
\hline & & & & & & $\begin{array}{c}\text { Individual } \\
\text { Speci. }\end{array}$ & Ave. & $\begin{array}{l}\text { Individual } \\
\text { Speci. }\end{array}$ & Avg. \\
\hline \multirow{12}{*}{$\begin{array}{l}\text { Popu- } \\
\text { lus }\end{array}$} & \multirow{3}{*}{ Control } & 1 & 10.80 & & & & & 25 & \multirow{3}{*}{23.66} \\
\hline & & 2 & 9.62 & & & & & 20 & \\
\hline & & 3 & 11.06 & & & & & 26 & \\
\hline & \multirow{3}{*}{$\begin{array}{l}\text { Treated } \\
\text { with 3\% } \\
\text { solution }\end{array}$} & 1 & 10.23 & 16.07 & 57.08 & 0.175 & \multirow{3}{*}{0.286} & 14 & \multirow{3}{*}{12.66} \\
\hline & & 2 & 10.55 & 18.85 & 78.67 & 0.248 & & 11 & \\
\hline & & 3 & 10.39 & 24.91 & 139.74 & 0.435 & & 13 & \\
\hline & \multirow{3}{*}{$\begin{array}{l}\text { Treated } \\
\text { with } 5 \% \\
\text { solution }\end{array}$} & 1 & 10.95 & 19.29 & 76.16 & 0.417 & \multirow{3}{*}{0.336} & 6 & \multirow{3}{*}{4.66} \\
\hline & & 2 & 9.61 & 15.65 & 62.85 & 0.302 & & 3 & \\
\hline & & 3 & 9.59 & 15.23 & 58.81 & 0.282 & & 5 & \\
\hline & \multirow{3}{*}{$\begin{array}{l}\text { Treated } \\
\text { with } 8 \% \\
\text { solution }\end{array}$} & 1 & 9.98 & 23.23 & 134.62 & 1.07 & \multirow{3}{*}{0.965} & $<5$ & \multirow{3}{*}{4.33} \\
\hline & & 2 & 9.71 & 24.56 & 152.93 & 1.19 & & 3 & \\
\hline & & 3 & 10.44 & 18.47 & 76.91 & 0.642 & & 5 & \\
\hline \multirow{12}{*}{ Pine } & \multirow{3}{*}{ Control } & 1 & 5.20 & & & & & 18 & \multirow{3}{*}{23.66} \\
\hline & & 2 & 5.18 & & & & & 27 & \\
\hline & & 3 & 5.39 & & & & & 26 & \\
\hline & \multirow{3}{*}{$\begin{array}{l}\text { Treated } \\
\text { with 3\% } \\
\text { solution }\end{array}$} & 1 & 5.23 & 8.80 & 68.26 & 0.107 & \multirow{3}{*}{0.123} & 15 & \multirow{3}{*}{12.33} \\
\hline & & 2 & 5.35 & 8.62 & 61.12 & 0.098 & & 8 & \\
\hline & & 3 & 4.68 & 10.16 & 117.09 & 0.164 & & 14 & \\
\hline & \multirow{3}{*}{$\begin{array}{l}\text { Treated } \\
\text { with 5\% } \\
\text { solution }\end{array}$} & 1 & 5.13 & 10.75 & 109.55 & 0.281 & \multirow{3}{*}{0.463} & 2 & \multirow{3}{*}{3.66} \\
\hline & & 2 & 5.22 & 11.26 & 115.70 & 0.302 & & 3 & \\
\hline & & 3 & 5.16 & 11.29 & 118.79 & 0.806 & & 6 & \\
\hline & \multirow{3}{*}{$\begin{array}{l}\text { Treated } \\
\text { with } 8 \% \\
\text { solution }\end{array}$} & 1 & 5.16 & 8.93 & 73.06 & 0.801 & \multirow{3}{*}{0.569} & 1 & \\
\hline & & 2 & 4.75 & 10.34 & 117.68 & 0.447 & & 0.0 & 2.33 \\
\hline & & 3 & 4.72 & 10.46 & 121.61 & 0.459 & & 6 & \\
\hline
\end{tabular}

Results of this investigation on mold's growth prevention by applying pyrolysis date palm waste derived PA are presented in Table 2 and Figs. 2 and 3. 


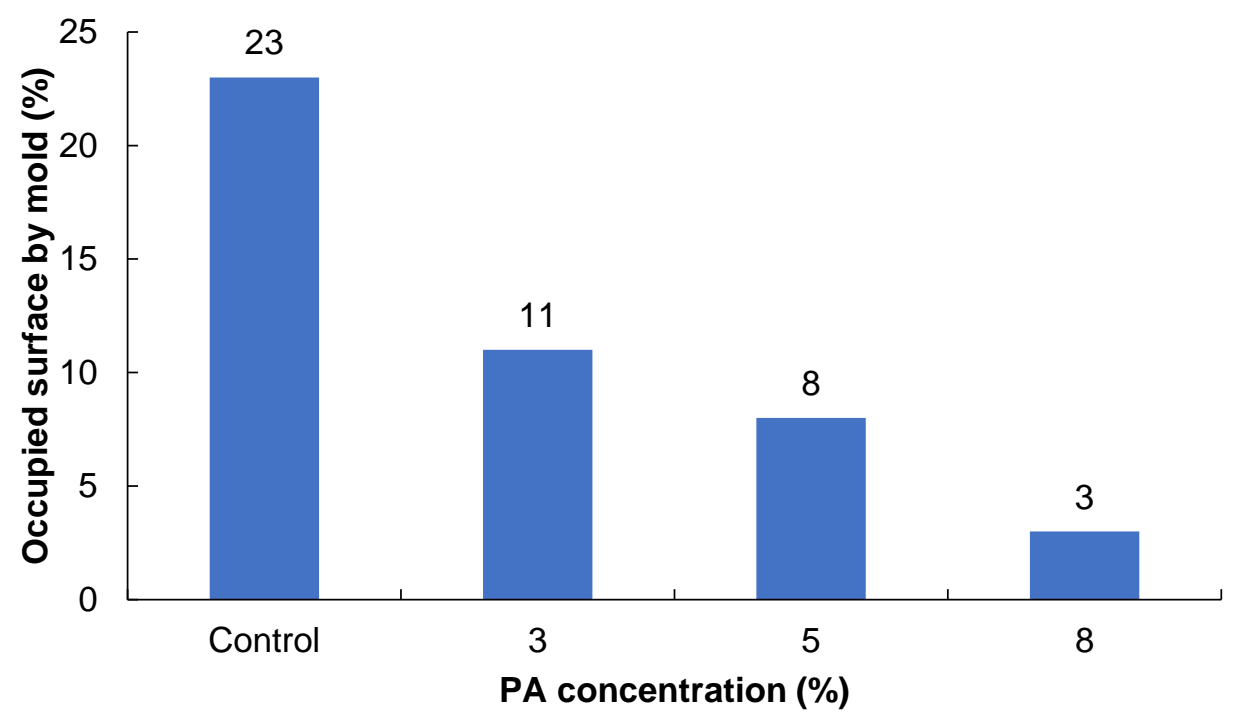

Fig. 2. Occupied surface of specimens by mold (\%) on poplar treated and untreated wood

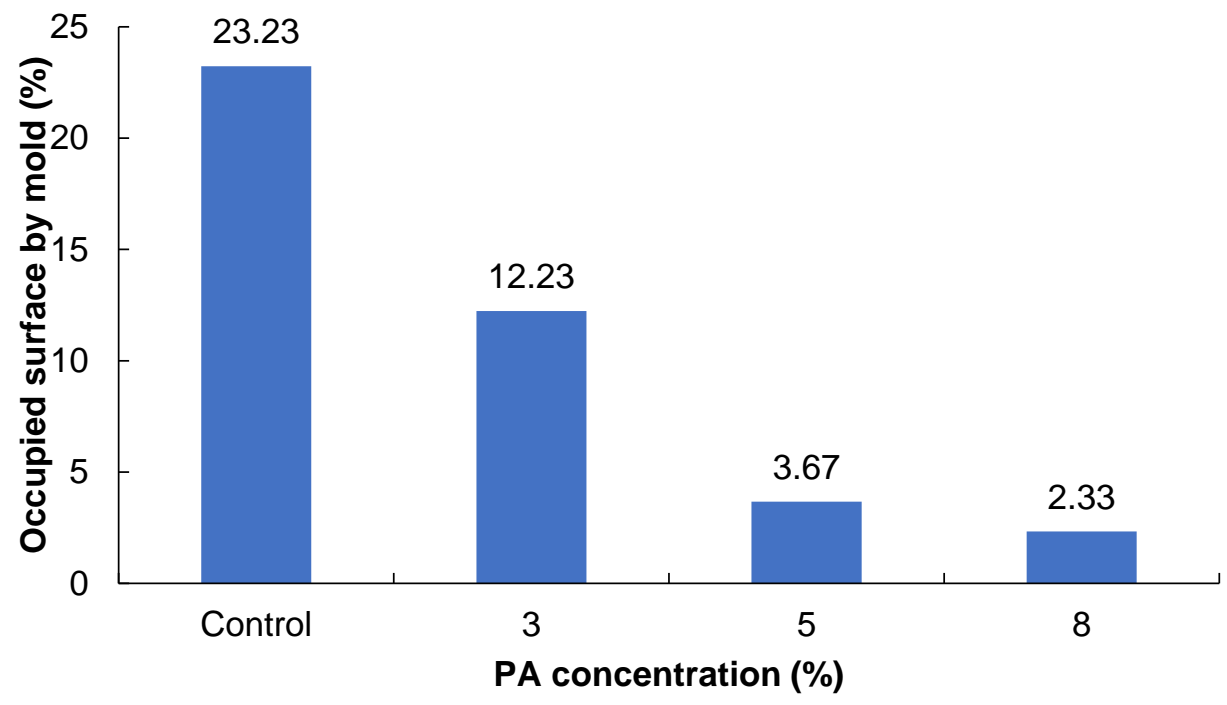

Fig. 3. Occupied surface of specimens by mold (\%) on pine treated and untreated wood

Freshly sawn lumber contains saps, which are nutrients for molds and fungi. Molds are not able to damage structure of wood, but dark pigment in their spores will discolor wood (blue, dark, or green) (Ebrahimi 2011; Reinprecht 2016). Discolorations reduces economical values of lumber in their marketplace. The economic importance of preventing stain in wood is so important that saw mills and kiln dryer owners in North America have referred to the Forest Products Laboratory (USDA) for developing a technique using any chemicals that can inhibit mold growth on green lumber. Initial trials revealed that reducing moisture content of lumber to below 20\% is a useful action (Ebrahimi 2011). Stacking green lumber after being sawn helps but may not provide a sufficient drying rate, particularly in humid regions where relative humidity mitigates drying rate and mold agents will find the chance to initiate their growth and expand their settlement on lumber. Accelerating air circulation through stacked lumber works to some extent in lowering moisture content below susceptible level for molds. Even applying these types of 
prohibitive care may not serve the purposes in some places where high relative humidity is present all year around.

Continuation of investigating efforts has found that sodium pantaclorophenate and ethyl phenate mercury can prevent mold growth quite effectively (Ebrahimi 2011). These chemicals were in use for several years until it was recognized that both of them are harmful for workers who work in mills and also these compounds contaminate run-off sources of water. Therefore, the Environmental Protection Agency (EPA) has prohibited uses of these chemicals in 1970 (Ebrahimi 2011). Since then, interested researchers have focused on the usage of organic compounds to meet these objectives ( $\mathrm{Qu}$ et al. 2019).

In this study, the effectiveness of pyrolysis date palm waste derived PA for prevention of mold (Aspergillus) growth on poplar and pine wood specimens was evaluated by observing the percentage of the ratio of occupied surface by mold to total surface of specimen as comparative measure. Evaluation of this criterion was made using image-J software. Table 2 contains the details of collected experimental data. The last two columns of this table show values of mentioned criteria over individual control and treated set of specimens. Mean value for control set of poplar specimens was 23.66 and for those of treated ones $(3,5$, and $8 \%)$ the values were $12.66,4.66$, and 4.33 , respectively. In the same order for pine specimens these were 23.66, 12.33, 3.66, and 2.33. Figures 2 and 3 present these values graphically. The physical status of experimental specimens is shown in Fig. 4. It was evident that mold was not able to exhibit its varying intensity of discoloration on specimens of poplar and pine treated with 5 and $8 \%$ of solutions (the last two columns of specimens in Fig. 4). The $3 \%$ solution on pine wood was more effective than on poplar.
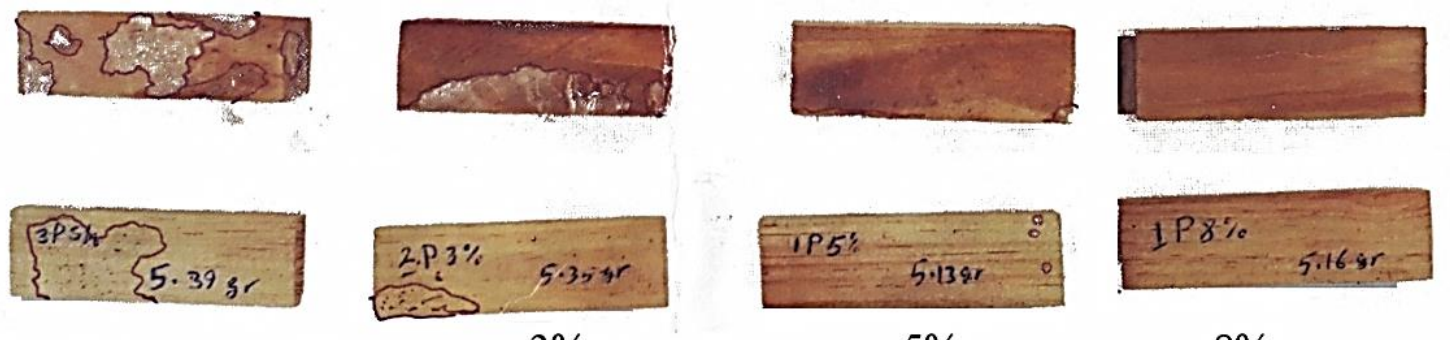

$3 \%$

$5 \%$ $8 \%$

Mold Test Specimens

Fig. 4. Physical status of mold contaminated samples after incubation: above row is pine sample, and below one is poplar. and Fig. 5.

Weight losses of specimens after the decay resistance test are presented in Table 3

The effectiveness of pyrolysis-derived bio-oil in preserving beech wood against fungus (T. versicolor) has been characterized through weight reduction between control set and impregnated set of specimens. After treating with solutions that contained 3, 5, and 8\% of bio-oil (by weight), the weight reductions of specimens were recorded, and the weight after treatment was considered for comparison measures. The obtained data are listed in Table 3. The last two columns show the percent of weight reduction of individual specimens in each set and their corresponding mean values. 
Table 3. Data of Experiment of Decay Fungus on Beech Specimens Treated with PA

\begin{tabular}{|c|c|c|c|c|c|c|c|c|c|}
\hline \multirow[t]{2}{*}{$\begin{array}{l}\text { Specimen } \\
\text { Set }\end{array}$} & \multirow[t]{2}{*}{$\begin{array}{c}\text { Specimen } \\
\text { No. }\end{array}$} & \multirow[t]{2}{*}{$\begin{array}{l}\text { Initial } \\
\text { Weight } \\
\text { (g) }\end{array}$} & \multirow[t]{2}{*}{$\begin{array}{l}\text { Weight } \\
\text { After } \\
\text { Treatment } \\
\text { (g) }\end{array}$} & \multicolumn{2}{|c|}{$\begin{array}{c}\text { Retention, \% } \\
\text { of Initial } \\
\text { Weight }\end{array}$} & \multicolumn{2}{|c|}{$\begin{array}{l}\text { Net Weight of } \\
\text { Oil in } \\
\text { Samples (g) }\end{array}$} & \multicolumn{2}{|c|}{$\begin{array}{c}\% \text { of Weight } \\
\text { Loss Based } \\
\text { on Weight } \\
\text { After } \\
\text { Treatment }\end{array}$} \\
\hline & & & & Indiv. & Avg. & $\begin{array}{l}\text { Ind. } \\
\text { Speci }\end{array}$ & Avg. & Indiv. & Avg. \\
\hline \multirow{4}{*}{ Control } & 1 & 1.88 & & & & & & 12 & \multirow{4}{*}{7.90} \\
\hline & 2 & 1.96 & & & & & & 7.20 & \\
\hline & 3 & 1.87 & & & & & & 6.40 & \\
\hline & 4 & 1.97 & & & & & & 6 & \\
\hline \multirow{4}{*}{$\begin{array}{l}\text { Treated } \\
\text { with 3\% } \\
\text { Solution }\end{array}$} & 1 & 1.73 & 3.40 & 96.53 & \multirow{4}{*}{88.90} & 0.050 & \multirow{4}{*}{0.049} & 7.20 & \multirow{4}{*}{5.70} \\
\hline & 2 & 1.98 & 3.62 & 82.82 & & 0.049 & & 6.40 & \\
\hline & 3 & 1.76 & 3.43 & 94.88 & & 0.50 & & 4.12 & \\
\hline & 4 & 1.92 & 3.48 & 81.25 & & 0.049 & & 5 & \\
\hline \multirow{4}{*}{$\begin{array}{l}\text { Treated } \\
\text { with } 5 \% \\
\text { Solution }\end{array}$} & 1 & 1.70 & 3.26 & 91.76 & \multirow{4}{*}{90.32} & 0.078 & \multirow{4}{*}{0.082} & 8.47 & \multirow{4}{*}{5.90} \\
\hline & 2 & 1.73 & 3.32 & 91.90 & & 0.079 & & 5.35 & \\
\hline & 3 & 1.95 & 3.85 & 97.43 & & 0.095 & & 6.50 & \\
\hline & 4 & 1.92 & 3.46 & 80.20 & & 0.077 & & 3.25 & \\
\hline \multirow{4}{*}{$\begin{array}{l}\text { Treated } \\
\text { with } 8 \% \\
\text { Solution }\end{array}$} & 1 & 1.91 & 3.45 & 80.62 & \multirow{4}{*}{96.13} & 0.121 & \multirow{4}{*}{0.141} & 5.5 & \multirow{4}{*}{5.97} \\
\hline & 2 & 2.01 & 4.13 & 105.47 & & 0.169 & & 3.62 & \\
\hline & 3 & 1.85 & 3.66 & 97.83 & & 0.144 & & 8.12 & \\
\hline & 4 & 1.65 & 3.31 & 100.60 & & 0.132 & & 6.64 & \\
\hline
\end{tabular}

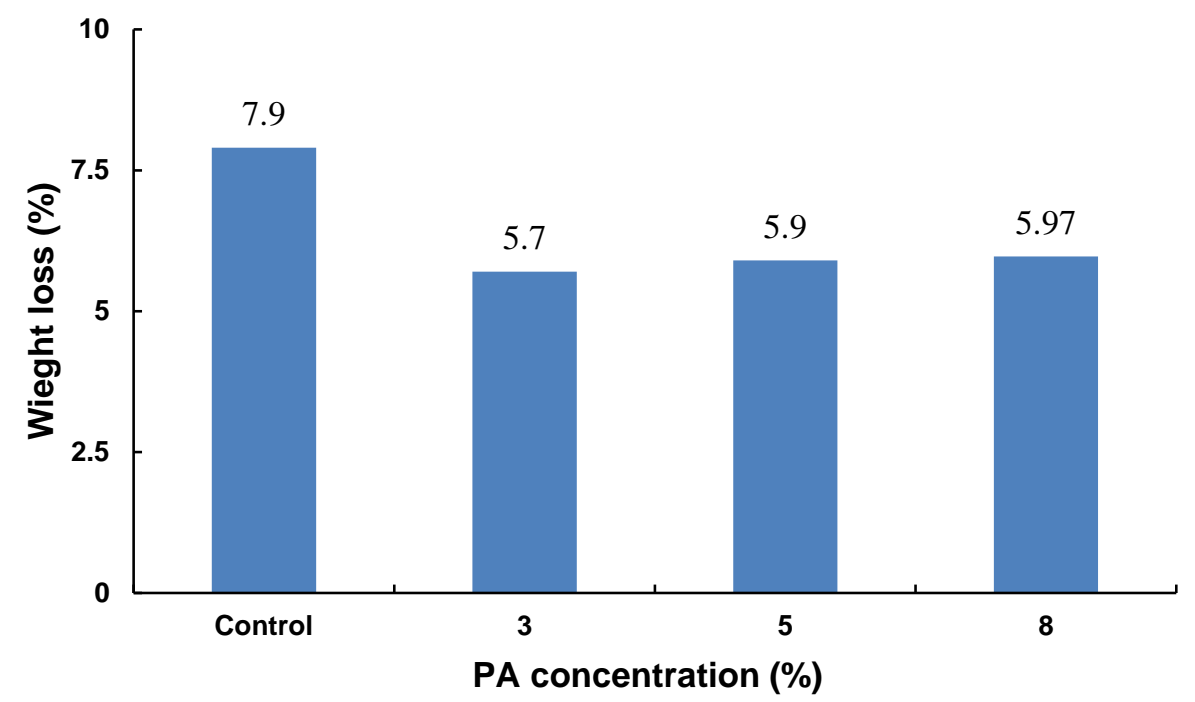

Fig. 5. Average weight loss of beech specimens treated with date palm waste derived PA: contaminated with Trametes versicolor

The average weight reduction based on weight after impregnation for the control set was $7.90 \%$, and for the sets of treated samples with 3,5 , and $8 \%$ of solutions, the results were 5.70, 5.90, and 5.97\%, respectively. These values are shown in Fig. 4. The weight reduction in treated samples, when compared with control ones, seemed remarkable. 
Physical status of specimens after incubation period, is shown in Fig. 6. The 8\% PA solution satisfactorily protected beech wood from $T$. versicolor (Fig. 6).

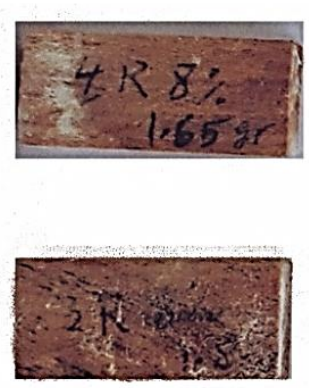

$8 \%$
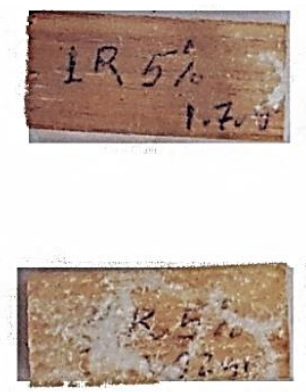

$5 \%$
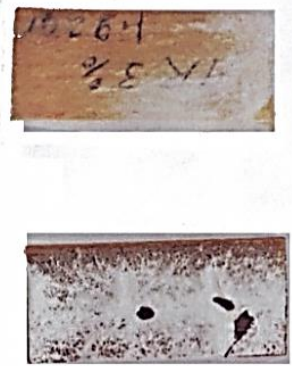

$3 \%$
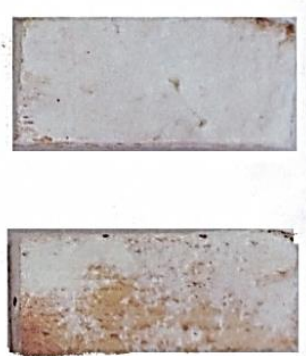

Control

Fungus Test Specimens

Fig. 6. Physical status of fungus contaminated samples after incubation: above row is pine sample, and below is poplar

Date palm wastes are fibrous materials and may seem to be an option in replacing and other natural fibers in producing fiber-based products. However, this does look right, since it will require continuous removal of wastes from palm groves, which in long run causes soil degradation in palm grooves, regarding its fertility and nutrient balance. In addition, collection and transportation of these wastes, a light and voluminous substance, to an installation producing fiber-based products with feasible capacity, may not be economically justified.

Productivity in utilization of date palm wastes by establishment of pyrolysis process installation is an approval approach, because it is less capital intensive and through this process two products are produced. Producing these two products with organic origin will be of no harm to the environment and their uses in agricultural activities are rather broad, including addition to the soils as fertilizer agent.

\section{CONCLUSIONS}

1. Results of testing pyrolysis-derived acid (PA) obtained from date palm wastes in controlling mold's growth on wood and consequent discoloration, have shown promise.

2. The effectiveness of this PA in terms of its concentration in treating solutions is species-dependent, because by visual inspection its $3 \%$ solution on pine wood performed better on poplar one. Therefore, effectiveness of its higher concentrations in treating solution may vary on different species of wood.

3. The application of $8 \%$ PA as a treating solution showed a successful result in protecting beech wood against $T$. versicolor fungus.

4. This PA with antifungal property can be used as an organic pesticide. 


\section{ACKNOWLEDGMENTS}

This study was funded by Iran National Science Foundation, Project No. 96010137.

\section{REFERENCES CITED}

Ahmadi, K., Gholizadeh, H., Ebadzadeh, H., Hosseinpour, R., Abdshah, H., Kazemian, A., and Rafiei, M. (2015). "Iranian Statistical Yearbook of Agriculture, Horticulture Products," Ministry of Agriculture. Tehran, I.R. Iran, 401 pp.

Al-Wabel, M. I., Usman, A. R. A., Al-Farraj, A. S., Ok, Y. S., Abduljabbar, A., Al-Faraj, A. I., and Sallam, A. S. (2019). "Date palm waste biochars alter a soil respiration, microbial biomass carbon, and heavy metal mobility in contaminated mined soil," Environmental Geochemistry and Health 41(4), 1705-1722. DOI: 10.1007/s10653017-9955-0

AWPA E24-16 (2017). "Laboratory method for evaluating the mold resistance of woodbased materials: Mold chamber test," American Wood Protection Association, Birmingham, Alabama, USA.

Beesley, L., Moreno-Jiménez, E., Gomez-Eyles, J. L., Harris, E., Robinson, B., and Sizmur, T. (2011). "A review of biochars' potential role in the remediation, revegetation and restoration of contaminated soils," Environmental Pollution 159(12), 3269-3282. DOI: 10.1016/j.envpol.2011.07.023

Bensidhom, G., Hassen-Trabelsi, A. B., Alper, K., Sghairoun, M., Zaafouri, K., and Trabelsi, I. (2018). "Pyrolysis of date palm waste in a fixed-bed reactor: characterization of pyrolytic products," Bioresource Technology 247(1), 363-369. DOI: 10.1016/j.biortech.2017.09.066

Ebrahimi, G. (2011). Wood Discoloration. Iranian Scientific Association of Wood and Paper Industries, Karaj, Iran. 64p.

EN 113 (1997). "Wood preservatives. Test method for determining the protective effectiveness against wood destroying basidiomycetes. Determination of the toxic values," European Committee for Standardization, Brussels, Belgium.

Gai, X., Wang, H., Liu, J., Zhai, L., Liu, S., Ren, T., and Liu, H. (2014). "Effects of feedstock and pyrolysis temperature on biochar adsorption of ammonium and nitrate," PloS one 9(12), e113888. DOI: 10.1371/journal.pone.0113888

Hussain, A., Farooq, A., Bassyouni, M. I., Sait, H. H., El-Wafa, M. A., Hasan, S. W., and Ani, F. N. (2014). "Pyrolysis of Saudi Arabian date palm waste: A viable option for converting waste into wealth," Life Science Journal 11(12), 667-671.

DOI:10.7537/MARSLSJ111214.126

Jonoobi, M., Shafie, M., Shirmohammadli, Y., Ashori, A., Hosseinabadi, H. Z., and Mekonnen, T. (2019). "A review on date palm tree: Properties, characterization and its potential applications," Journal of Renewable Materials 7(11), 1055-1075. DOI:10.32604/jrm.2019.08188

Jouiad, M., Al-Nofeli, N., Khalifa, N., Benyettou, F., and Yousef, L. F. (2015). "Characteristics of slow pyrolysis biochars produced from rhodes grass and fronds of edible date palm," Journal of Analytical and Applied Pyrolysis 111, 183-190. DOI: 10.1016/j.jaap.2014.10.024 
Oramahi, H. A., Yoshimura, T., Diba, F., and Setyawati, D. (2018). “Antifungal and antitermitic activities of wood vinegar from oil palm trunk," Journal of Wood Science 64(3), 311-317. DOI: 10.1007/s10086-018-1703-2

Prasad, R., and Power, J. F. (1991). "Crop residue management," in: Advances in Soil Science, Vol. 15, B. A. Stewart (ed.), Springer, New York, NY. DOI: 10.1007/978-14612-3030-4_5

Qu, S., Yang, K., Chen, L., Liu, M., Geng, Q., He, X., Li, Y., Liu, Y., and Tian, J. (2019). "Cinnamaldehyde, a promising natural preservative against aspergillus flavus." Frontiers in Microbiology 10(1), 2895. DOI: 10.3389/fmicb.2019.02895

Reinprecht, L. (2016). Wood Deterioration, Protection, and Maintenance, London: Wiley Blackwell, 364 pp.

Ronsse, F., Van Hecke, S., Dickinson, D., and Prins, W. (2013). "Production and characterization of slow pyrolysis biochar: Influence of feedstock type and pyrolysis conditions," GCB Bioenergy 5(2), 104-115. DOI: 10.1111/gcbb.12018

Skjemstad, J. O., Reicosky, D. C., Wilts, A. R., and McGowan, J. A. (2002). "Charcoal carbon in US agricultural soils," Soil Science Society of America Journal 66(4), 12491255. DOI: $10.2136 /$ sssaj2002.1249

Usman, A. R., Abduljabbar, A., Vithanage, M., Ok, Y. S., Ahmad, M., Ahmad, M., Elfaki, J., Abdulazeem, S. S., and Al-Wabel, M. I. (2015). "Biochar production from date palm waste: Charring temperature induced changes in composition and surface chemistry," Journal of Analytical and Applied Pyrolysis 115, 392-400. DOI: 10.1016/j.jaap.2015.08.016.

Usman, A., Sallam, A., Zhang, M., Vithanage, M., Ahmad, M., Al-Farraj, A., Ok, Y.S., Abduljabbar, A., and Al-Wabel, M., (2016). "Sorption process of date palm biochar for aqueous Cd (II) removal: Efficiency and mechanisms," Water, Air, \& Soil Pollution 227(12), 449. DOI: 10.1007/s11270-016-3161-z.

Woolf, D., Amonette, J. E., Street-Perrott, F. A., Lehmann, J., and Joseph, S. (2010). "Sustainable biochar to mitigate global climate change," Nature Communications 1(1), 1-9. DOI: 10.1038/ncomms 1053

Article submitted: November 9, 2020; Peer review completed: January 31, 2021; Revised version received and accepted: February 9, 2021; Published: May 24, 2021.

DOI: 10.15376/biores.16.3.5000-5010 